КИСЕЛЬОВ О. О., кандидат юридичних наук, доцент, ректор (Дніпровський гуманітарний університет)

Д'ЯЧЕНКО Г. Є., студент юридичного факультету (Дніпровський гуманітарний університет)

\title{
МІЖНАРОДНІ СТАНДАРТИ ЗАХИСТУ ПРАВ ОСІБ, ЯКІ Є ПОТЕРПІЛИМИ ВІД КРИМІНАЛЬНИХ ПРАВОПОРУШЕНЬ
}

Стаття присвячена аналізу міжнародних стандартів прав осіб, які є потерпілими від кримінальних правопорушень. Запропоновано визначити міжнародні стандарти захисту прав потерпілих від кримінальних правопорушень як закріплену в джерелах міжнародного права систему норм і принципів, що на основі загальновизнаних уявлень про права особи встановлює права потерпілого й умови їх обмеження, механізми і гарантії реалізації таких прав, що 3 урахуванням особливостей порядку правового регулювання мають бути втілені та конкретизовані в національних правових системах. 3'ясовано сутність процесуального становища потерпілого, розкрито зміст міжнародних стандартів захисту прав потерпілого, надано визначення понять «потерпілий - фізична особа» та «потерпілий - юридична особа». Досліджено процесуальні права потерпілого як основа його процесуального статусу. Виявлено недоліки їх правової регламентації та запропоновано шляхи їх усунення. Сформульовано низку пропозицій, спрямованих на вдосконалення процесуального становища потерпілого в особливих порядках кримінального провадження (провадження у формі приватного обвинувачення та провадження на підставі угоди про примирення). Проаналізовано теоретичні основи забезпечення прав і законних інтересів потерпілого у кримінальному процесі. Досліджено основні структурні елементи кримінального процесуального механізму забезпечення прав і законних інтересів потерпілого у кримінальному процесі. Розглянуто роль особистої участі потерпілого у правозахисному механізмі кримінального процесу. Висвітлене місце представника потерпілого у правозахисному механізмі кримінального процесу. Виокремленні основні владні суб'єкти кримінального процесу в механізмі забезпечення прав і законних інтересів потерпілого. Визначені особливості забезпечення прав і законних інтересів потерпілого конкретними владними суб'єктами кримінального процесу. Розглянуті прокурорські наглядові повноваження та судово-контрольні форми забезпечення прав і законних інтересів потерпілого в кримінальному процесі.

Ключові слова: захист прав потерпілого, кримінальне правопорушення, кримінальний процес, міжнародні стандарти, потерпілий, правозахисний механізм, приватне обвинувачення, процесуальне становище.

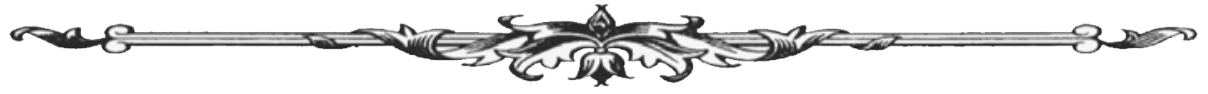


The article is sanctified to the analysis of international standards of rights for persons, that are victims from criminal offences. It is suggested to define the international standards of protection of rights suffering from criminal offences as envisaged in the sources of international law system of norms and principles, that on the basis of the universally recognized ideas about rights for personality sets rights for a victim and terms of their limitation, mechanisms and guarantees of realization of such rights, that taking into account the features of order of the legal adjusting must be incarnate and specified in the national legal systems. Essence of judicial position of victim is found out, maintenance of international standards of protection of rights for a victim is exposed, the decision of concepts is given "a victim is a physical person" and "victim is a legal entity". Judicial rights for a victim are investigational as basis of him judicial status. Defects are educed them legal regulation and the ways of their removal are offered. The row of the suggestions sent to perfection of judicial position of victim in the special orders of criminal realization (realization in form a private prosecution and realization on the basis of agreement about reconciliation) is set forth. Theoretical bases of providing of rights and legal interests of victim are analysed in a criminal process. The basic structural elements of criminal judicial mechanism of providing of rights and legal interests of victim are investigational in a criminal process. The role of the personal participation of victim is considered in the mechanism of criminal process. The lighted up place of representative suffering is in the mechanism of criminal process. Selection basic imperious subjects of criminal process in the mechanism of providing of rights and legal interests of victim. Certain features of providing of rights and legal interests of victim by the concrete imperious subjects of criminal process. Public prosecutor's observant plenary powers and judicial-control forms of providing of rights and legal interests of victim are considered in a criminal process.

Key words: protection of rights for a victim, criminal offence, criminal process, international standards, victim, mechanism, private prosecution, judicial position.

Вступ. Національне кримінальне судочинство будується відповідно до Конституції України та міжнародних стандартів, зокрема, стандартів захисту прав осіб, потерпілих від кримінальних правопорушень. Нині, коли стає помітним значний вплив норм міжнародного права на внутрішнє законодавство кожної країни, $є$ підстави вважати правовою ту державу, яка у своїй правовій системі повною мірою використовує потенціал міжнародних норм. Саме тому особливого значення набуває з'ясування поняття та змісту міжнародних стандартів захисту прав потерпілих і їх реалізація у кримінальному процесі України.

Поняття «міжнародні стандарти прав людини», «міжнародні стандарти захисту прав потерпілих осіб» досліджувалися в роботах Т.Г. Андрусяка, В.Г. Буткевича, М.В. Вітрука, А.Д. Гусєва, І.М. Ібрагімова, О.В. Капліної, К.І. Кухти, О.П. Кучинської, В.В. Лазарєва, С.Б. Лугвина, І.І. Лукашука, О.В. Малько, Л.С. Мамута, П.М. Рабіновича, Т.Л. Сироїд, М.С. Строговича, Н.Б. Федорчука, М.I. Хавронюка, С.В. Шевчука та ін. Крім вітчизняних учених, вивченням стандартів захисту прав особи займалися зарубіжні науковці-Р. Алстон, В. Бернс, Д. Донеллі, П. Касрін, Н. Кренстон, В. де Куплін, А. Мілн, Н. Неновські та ін.

Вивчаючи окреслене питання, можемо констатувати, що на рівні міжнародних угод єдиного визначення понять «міжнародні стандарти прав людини» і «стандарти захисту прав осіб, потерпілих від кримінальних правопорушень» немає, як і не містить їх чинне законодавство України. У юридичній літературі поняття «міжнародні стандарти захисту прав людини» нерідко ототожнюється із правами особи або із зобов'язаннями держав-учасниць за міжнародними договорами, чи із принципами міжнародного права тощо.

Постановка завдання. Метою статті $\epsilon$ характеристика міжнародних стандартів захисту прав осіб, які є потерпілими від кримінальних правопорушень.

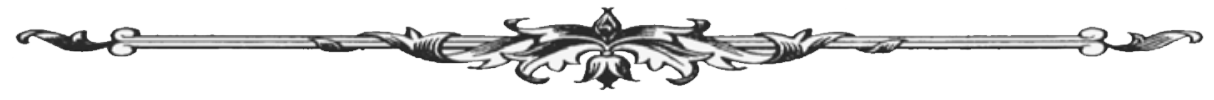


Результати дослідження. Головними характеристиками прав людини в західній концепції виступають їх невідчужуваність, фундаментальність та індивідуальний характер, а також природно-правове походження. В азійській концепції перевага надається не правам, а обов'язкам індивіда перед суспільством та державою. Суспільство переважає над інтересами індивіда в Азії, натомість на Заході права індивіда вище за інтереси суспільства. Саме цим і пояснюється той факт, що на території Європейського Союзу діє принцип юридичної визначеності, що не дозволяє державі посилатися на відсутність певного нормативного акта, який визначає механізм реалізації прав та свобод громадян, закріплених у Конституціях чи інших актах [1, с. 89-90].

У юридичній літературі міжнародні стандарти прав людини пропонується розуміти як норми, які відображають загальновизнані принципи міжнародного права стосовно прав людини і регулюють відносини, що складаються в ході їх реалізації в різних сферах судочинства [2, с. 310$]$

На загальнонауковому рівні прийнято вважати, що міжнародні стандарти захисту прав людини містяться в численних документах, прийнятих в рамках Ради Свропи, зокрема, Статуті Ради Європи (1949р.); Конвенції про захист прав людини й основоположних свобод (1950 р.), і в Протоколах до неї, а також в Декларації основних принципів правосуддя для жертв злочинів і зловживання владою (1985 р.).

Досліджуючи питання міжнародних стандартів захисту прав особи у кримінальному процесі та потерпілого, зокрема, наголосимо, що в науці цьому питанню майже не приділяється увага. У юридичній літературі можна знайти лише такі визначення. Міжнародні стандарти захисту прав особи в кримінальному судочинстві - це особливі орієнтири захисту прав особи в кримінальному судочинстві. Під ними слід розуміти не тільки загальновизнані норми і принципи міжнародного права, а й міжнародні договори, і численні норми законодавчих актів [3, с. 152]. Щодо європейських стандартів захисту, то європейськими стандартами захисту прав людини у кримінальному процесі є звід основних принципів забезпечення прав людини, встановлений міжнародними нормативно-правовими актами, які є обов'язковими для виконання всіма національними органами під час здійснення кримінального судочинства, у разі їх ратифікації Верховною Радою України [4, с. 381].

На основі викладеного пропонуємо таке визначення міжнародних стандартів захисту прав потерпілого - це закріплена в джерелах міжнародного права система норм і принципів, що на основі загальновизнаних уявлень про права особи встановлює права потерпілого та умови їх обмеження, механізми і гарантії реалізації таких прав, що з урахуванням особливостей порядку правового регулювання мають бути втілені й конкретизовані в національних правових системах. Вважаємо за необхідне проаналізувати кожен міжнародний стандарт захисту прав потерпілого з метою визначення повноти їх розкриття в чинному кримінальному процесуальному законодавстві, особливостей реалізації в кримінальному провадженні та виявлення можливих резервів для вдосконалення.

1. Доступ до правосуддя та справедливе поводження. В юридичній літературі немає єдиного підходу до визначення поняття «доступ до правосуддя». За чинним Кримінальним процесуальним кодексом України (далі - КПК України) доступ до правосуддя - це засада кримінального провадження. Зокрема, у ст. 21 КПК України закріплено: «кожному гарантується право на справедливий розгляд та вирішення справи в розумні строки незалежним і неупередженим судом, створеним на підставі закону...». Стосовно потерпілого, на нашу думку, його право на доступ до правосуддя конкретизується в ч. 2 ст. 55 КПК України: права і обов'язки потерпілого виникають у особи з моменту подання заяви про вчинення щодо неї кримінального правопорушення або заяви про залучення ii до провадження як потерпілого. Під час досудового розслідування потерпілий має право на негайне прийняття і реєстрацію заяви про кримінальне правопорушення, визнання його потерпілим, а також він має право на отримання від уповноваженого органу, до якого він подав заяву, документа, що підтверджує її прийняття і реєстрацію (п. 1,2 ч. 2 ст. 56 КПК України) [5].

Враховуючи викладене вище, можна виокремити систему прав потерпілого, які спрямовані на реалізацію стандарту доступності правосуддя. Таку систему складають наступні права потерпілого: на негайне прийняття і реєстрацію заяви про кримінальне правопорушення, визнання потерпілим (п. 1 ч. 2 ст. 56 КПК України); отримувати від уповноваже-

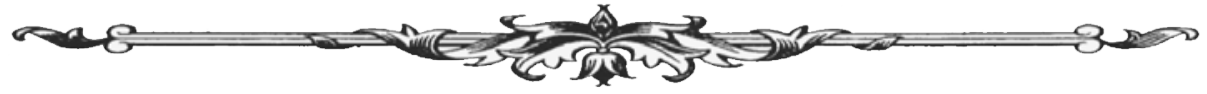


ного органу, до якого він подав заяву, документ, що підтверджує їі прийняття і реєстрацію (п. 2 ч. 2 ст. 56 КПК України); на відшкодування завданої кримінальним правопорушенням шкоди в порядку, передбаченому законом (п. 10 ч. 1 ст. 56 КПК України); підтримувати обвинувачення в суді у разі відмови прокурора від підтримання державного обвинувачення або зменшення обсягу обвинувачення (ч. 3 ст. 338, ч. 2 ст. 340 КПК України).

2. Забезпечення права на справедливу реституцію жертвам, їх сім'ям або утриманцям. Згідно з Декларацією за відповідних обставин правопорушники чи треті особи, що несуть відповідальність за їх поведінку, повинні надавати справедливу реституцію жертвам, їх сім'ям чи утриманцям (ст. 8). Коли державні посадові особи або інші представники, що діють як офіційні чи напівофіційні, порушують національні кримінальні закони, жертви повинні отримати реституцію від держави, посадові особи чи представники якої несуть відповідальність за завдану шкоду (ст. 11 Декларації). Під терміном «національна установа 3 прав людини» у міжнародному праві розуміється орган, що відповідно до конституції або закону створюється урядом і функцією якого визначено захист і забезпечення прав людини [6, с. 281]. Таким чином, повноваження національної установи приймати скарги і вживати щодо них відповідних заходів слід розглядати як додатковий державний механізм забезпечення захисту прав особи.

3 огляду на вказане слід констатувати, що національна установа 3 прав людини може стати тим органом, до якого особа, якій завдано шкоди, може звернутися за захистом своїх прав. До ії переваг слід віднести відокремленість і незалежність від органів влади та посадових осіб, які завдали шкоду особі.

3. Забезпечення державою відшкодування потерпілому шкоди, завданої кримінальним правопорушенням. У п. 10 ст. 56 КПК України, серед іншого, також закріплюється право потерпілого на відшкодування завданої кримінальним правопорушенням шкоди. Проте постає питання: у який спосіб держава забезпечує реалізацію потерпілим цього права?

Відшкодування потерпілому завданої кримінальним правопорушенням шкоди за рахунок Державного бюджету розглядається науковцями як окремий спосіб відшкодування шкоди. У свою чергу, його можна класифікувати на дві групи: відшкодування шкоди, завданої незаконними рішеннями, діями чи бездіяльністю органу, що здійснює оперативнорозшукову діяльність, досудове розслідування, прокуратури або суду; відшкодування шкоди, завданої потерпілому внаслідок кримінального правопорушення.

4. Забезпечення права потерпілого на інформацію. Інформування як таке передбачає, що держава зобов'язана забезпечити особу необхідною інформацією, пов'язаною з ії особливим правовим статусом. Право потерпілого на інформацію має бути нормативно закріплене і забезпечене положеннями міжнародно-правових актів [7, с. 5]. Так, у Декларації зафіксовано, що жертвам надається інформація про їх роль та обсяг прав, строки проведення і хід судового розгляду, а також про результати розгляду їх справ (п. а ст. 6). Як наголошують науковці, забезпечення особам, які беруть участь у провадженні, права на інформацію при прийняті у справі рішень, що стосуються їх прав і свобод, $є$ гарантією реалізації права потерпілого на доступ до правосуддя.

Отже, у національному кримінальному процесуальному законодавстві визначається право потерпілого бути повідомленим про свої права та обов'язки, знати сутність підозри й обвинувачення, а також бути повідомленим про обрання, зміну чи скасування щодо підозрюваного, обвинуваченого заходів забезпечення кримінального провадження та закінчення досудового розслідування (п. 1, 2 ч. 1 ст. 56 КПК України).

5. Забезпечення права потерпілого на можливість вираження й урахування його думки. У Конвенції про захист прав людини і основоположних свобод зафіксовано, що кожен має право на свободу вираження поглядів (ст. 10). У Резолюції № 428 Парламентської Асамблеї Ради Європи вказано, що право на свободу вираження своєї думки включає в себе право шукати, отримувати, передавати, публікувати або поширювати інформацію [8, с. 395]. Аналізуючи норми кримінального процесуального закону, слід виділити положення, які стосуються додержання цього стандарту і реалізації потерпілим своїх прав на стадії досудового розслідування: лише за ініціативою потерпілого розпочинається кримінальне провадження у формі приватного обвинувачення (ст. 477 КПК України); у випадках відмови прокурора від обвинувачення або зміни

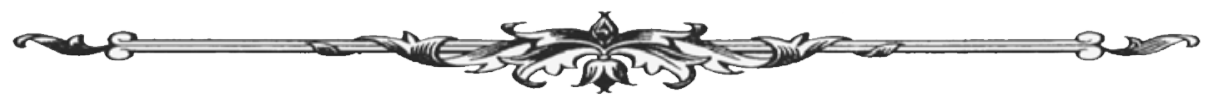


обвинувачення потерпілий має право погодитися або відмовитися підтримувати обвинувачення (ч. 3 ст. 338, ч. 2 ст. 340 КПК України); потерпілий має право ініціювати проведення слідчих (розшукових) дій, негласних слідчих (розшукових) дій та інших процесуальних дій (ч. 3 ст. 93 КПК України); суд зобов’язаний з'ясувати думку потерпілого щодо можливості звільнення підозрюваного від кримінальної відповідальності (ч. 2 ст. 288 КПК України); потерпілий має право ініціювати укладення угоди про примирення із підозрюваним у провадженнях щодо кримінальних проступків, злочинів невеликої чи середньої тяжкості та у кримінальних провадженнях у формі приватного обвинувачення (ч. 3 ст. 469 КПК України).

6. Забезпечення потерпілого правовою, медичною, соціальною та психологічною допомогою. Згідно зі ст. 2 Міжнародного пакту про громадянські і політичні права кожна держава зобов'язується забезпечити будь-якій особі, права і свободи якої порушено, ефективний засіб правового захисту та розвивати можливості судового захисту [9, с. 3-5]. Потерпілий має можливість отримати правову допомогу через інститут представництва. Так, відповідно до ч. 1 ст. 58 КПК України у кримінальному провадженні інтереси потерпілого може представляти особа, яка у кримінальному провадженні має право бути захисником.

Допомога професійного захисника, залученого для захисту за призначенням у випадках, передбачених КПК України та/або законом, що регулює надання безоплатної правової допомоги, здійснюється за рахунок коштів Державного бюджету України і є безоплатною для підозрюваного, обвинуваченого (ч. 3 ст. 120 КПК України). Водночас потерпілий забезпечується безоплатною правовою допомогою у вигляді представництва лише в окремих випадках. Вбачається, що це положення не відповідає міжнародним стандартам захисту прав потерпілих.

7. Забезпечення права потерпілого на безпеку. Закріплення вказаного стандарту на рівні національного законодавства $€$ необхідною гарантією, яка створена для того, щоб запобігти випадкам, коли потерпілий відмовляється від дачі показань, надання доказів, участі у провадженні через залякування або погрози з боку правопорушників. Нині в Законі України «Про Державний бюджет України на 2019 рік» у частині видатків не зазначено будьяких відомостей про кошти, які спрямовані на здійснення цих заходів, що, звісно, негативно впливає на забезпечення державою безпеки осіб у кримінальному судочинстві. Безумовно, такі заходи, як вже вказувалося, можуть бути профінансовані за рахунок коштів осіб, взятих під захист. У даному випадку очевидним є той факт, що не всі особи мають таку можливість. Однак навіть ті, хто мав постійне місце роботи та стабільний дохід, як правило, втрачають останнє (через те, що заходи безпеки передбачають зміну звичайного способу життя) та розраховують на допомогу держави. 3 огляду на це пропонуємо в обов'язковому порядку впровадити ефективні зміни в державну систему забезпечення безпеки осіб з метою захисту прав потерпілого у кримінальному провадженні. При цьому першочерговим кроком має стати створення та фінансування програм державного захисту осіб, які опинилися у сфері кримінального провадження та потребують захисту.

8. Забезпечення державою права на використання неофіційних механізмів врегулювання спорів. Насамперед зазначимо, що у світі діє дві концепції реагування на злочин: 1) класична (каральна), тобто переслідування державою в публічному порядку всіх осіб, які вчинили кримінальне правопорушення, і призначення їм за рішенням суду кримінального покарання; 2) альтернативна, згідно з якою держава відмовляється від переслідування із застосуванням певних альтернатив. Передусім дещо пояснимо: альтернативи кримінальному переслідуванню - це такі форми реакції на злочин, що пов'язані з відмовою від класичного кримінального переслідування і покарання, а також з виконанням особою, яка підлягає кримінальному переслідуванню, певних умов, що є підставою для ії звільнення від такого переслідування.

До останніх зазвичай відносять медіацію, посередництво, арбітраж. У багатьох країнах світу тривалий час розвивається новий підхід реагування на кримінальні правопорушення - відновне правосуддя як одна з форм неофіційних механізмів врегулювання конфліктів. Цей підхід базується на принципі усунення завданої потерпілому емоційної, майнової та фізичної шкоди. Ефективність відновного правосуддя вже визнана такими країнами, як Нова Зеландія, Норвегія, Німеччина, Франція та Польща, що включили програми відновного правосуддя до кримінального процесу як альтернативу чи доповнення до системи правосуддя [10, с. 261].

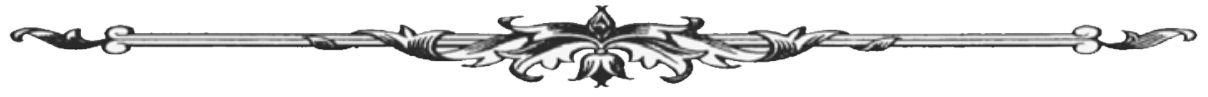


9. Створення національних фондів для виплати компенсації жертвам. Фонд допомоги потерпілим - це фонд, з якого жертви могли б отримати компенсацію моральної або матеріальної шкоди, коли не встановлено особу, яка вчинила кримінальне правопорушення, або якщо вона переховується від компетентних органів чи є неплатоспроможною. Такий фонд нині в Україні не створено, але існують концептуальні пропозиції та дослідження як на законодавчому, так і на науковому рівнях. Питання щодо організації Державного фонду допомоги потерпілим від злочинів порушувалися ще у Розпорядженні Президента України «Про заходи щодо активізації боротьби з корупцією і організованою злочинністю» (1995р.), в якому зверталася увага на необхідності координації роботи зі створення проекту Положення про Державний фонд допомоги потерпілим від злочинних посягань. За роки незалежності до Верховної Ради України було внесено декілька законопроектів щодо відшкодування шкоди потерпілим від кримінальних правопорушень за рахунок держави.

Висновки. Таким чином, вважаємо за потрібне створити в Україні як державний, так і громадський фонд для того, щоб відшкодування шкоди потерпілому відбувалося в повному обсязі та в найкоротший строк, для чого варто звернутися до міжнародного досвіду в цій сфері. Щодо міжнародних правових актів у сфері захисту прав і законних інтересів потерпілого, то вони втілюють основоположні засади і досвід міжнародного права, мають універсальний та узагальнюючий характер, але не є усталеними, а постійно вдосконалюються. Одним із перших актів, у якому звернено увагу на потерпілого (жертви злочинів) стала Конвенція про відшкодування шкоди жертвам насильницьких злочинів. Пізніше, у 1985 р. Генеральною Асамблеєю ООН було прийнято Декларацію основних принципів правосуддя жертв злочинів і зловживання владою, у якій вперше розкрито поняття «жертви злочинів», а одним із найважливіших прав визнано право на відшкодування шкоди. Особливістю зазначених актів $€$ те, що їх положення закріплюються загальними зусиллями держав за взаємною згодою, а встановлені вимоги мають однаковий ступінь імперативності. Чинним КПК України закріплено нове положення щодо застосовування практики Свропейського суду з прав людини (ст. ст. 8, 9 КПК України). Відтак вказане положення доцільно закріпити додатково й до інших загальних засад (принципів) кримінального провадження.

\section{Список використаних джерел:}

1. Абламський C.С. Захист прав і законних інтересів потерпілого у кримінальному провадженні : монографія / за аг. ред. О.О. Юхна. Харків : Панов, 2015. 240 с.

2. Шибіко В.П. Проблеми забезпечення прав потерпілого за новим КПК України 2012 року. Юридичний часопис Нац.. акад. внутр. справ. 2013. № 1. С. 307-313.

3. Уваров В.Г. Застосування практики Європейського Суду з прав людини та норми міжнародних-правових актів в удосконаленні кримінального процесуального судочинства України : монографія / за заг. ред. В.М. Тертишника. Дніпропетровськ, 2012. 268 с.

4. Татаров О.Ю. Досудове провадження в кримінальному процесі України : монографія. Донецьк : Промінь, 2012. 640 с.

5. Кримінальний процесуальний кодекс України : Закон України від 13 квітня 2012 р. № 4651-VI. URL: http://www.zakon.rada.gov.ua.

6. Савченко В.А. Кримінально-процесуальні гарантії (за законодавством України). Прикарпатський юридичний випуск. 2011. Вип. 1. С. 278-288.

7. Кучинська О.П. Поняття гарантій забезпечення прав учасників кримінального провадження. Адвокат. 2012. № 7 (142). С. 4-8.

8. Кримінальний процесуальний кодекс України. Науково-практичний коментар : у 2-х т. Т. 1 / О.М. Бандурка, Є.М. Блажівський та ін. ; за заг. ред. В.Я. Тація, В.П. Пшонки, А.В. Портнова. Харків : Право, 2012. 768 с.

9. Герасимчук О.П. Диспозитивні засади участі потерпілого у слідчих діях на досудовому розслідуванні. Часопис Академї адвокатури України. 2011. № 1 (10). С. 1-8.

10. Бандурка О.М. Теорія і практика оперативно-розшукової діяльності : монографія. Харків : Золота миля, 2012. 620 с.

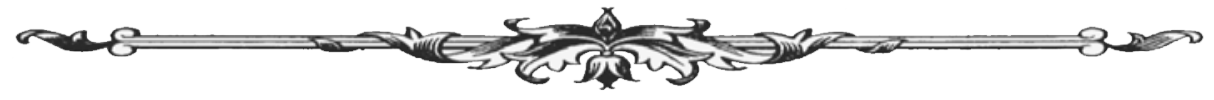

